\title{
A REVIEW OF THE OPHIDIOID FISHES OF JAPAN.
}

\author{
By David Starr Jordan and Henry W. Fowler, \\ Of the Leland Stanford Junior University.
}

In the present paper the writers give descriptions of the fishes of Japan belonging to the Zoarcidx, Ophidiidx, Brotulidx, and related families, known as Ophidioidea. The material examined is that collected by Jordan and Snyder in 1900, with that belonging to the U. S. National Museum, together with certain specimens collected by the U.S. Fish Commission steamer Albatross. The plates are drawn by Mr. William S. Atkinson.

\section{Group OPHIDIOIDEA.}

This group, as a whole, agrees with the Blennioidea in all respects, except that no spines are developed in any of the fins, save sometimes in the posterior part of the dorsal. From the Anacanthini, with which the Ophidioidea agree in the jugular ventrals and in the absence of spines, they are separated by the form of the hypercoracoid, which is perforate, as in ordinary fishes. The group is a very large and varied one, widely distributed in all seas. The characters here used are all superficial, no comparative study of the skeletons having been made.

a. Pseudobranchiæ well developed, very rarely small or obsolete.

$b$. Ventral fins jugular, inserted much behind the eye, often wanting, never filamentous.

c. Gill-membranes broadly united, free from the isthmus; ventrals wanting.

cc. Gill-membranes united to the isthmus, the gill-openings lateral Zoarcid

$b b$. Ventral fins developed as slender filaments attached at the throat not far behind eye.

e. Gill-membranes nearly separate, free from the isthmus; body scaly.

aa. Pseudobranchiæ absent (or rudimentary in some Brotulidx).

OPHIDIID E, IV.

$f$. Ventral fins wanting; no scales; vent at the throat.

Carapide, III.

$f f$. Ventral fins well developed; vent posterior, normal; dorsal fin single, low; ventral fins short.

Brotulide, V.

\section{Family I. CONGROGADID Æ.}

Body elongate, compressed, naked, or covered with very small scales. Head compressed. Mouth moderate, horizontal, the lower jaw the longer; teeth moderate, no barbels. Gills 4, a slit behind the fourth; 
pseudobranchiæ present. Gill-membranes more or less broadly connected, free from the isthmus. Dorsal fin long and low, beginning near the tip of the pectoral or the middle of body, of slender, jointed rays; anal similar to dorsal, both connected with the caudal fin; tail tapering; pectoral fins small; ventral fins wanting. Vent remote from the head, without papilla. Vertebræ numerous. As here understood, this family consists of a few species of shore fishes of the Pacific.

a. Body covered with small scales; tail pointed, the dorsal and anal united around it; a short superior lateral line about $\frac{1}{3}$ the length of the body. Hierichthys, 1 .

\section{HIERICHTHYS Jordan and Fowler, new genus.}

Hierichthys Jordan and Fowler, new genus (encryptes).

Body elongate, compressed, formed much as in Pholis, covered with small, smooth scales; a short superior lateral line about $\frac{1}{3}$ the length of the body; head compressed, rather pointed, the lower jaw projecting; mouth moderate, with a single series of strong, moderately large teeth in each jaw. Dorsal and anal low, continuous, of soft slender rays only, fully united with the caudal fin around the pointed tail; insertion of dorsal not far behind the nape; pectorals well developed; no ventrals. Japan.

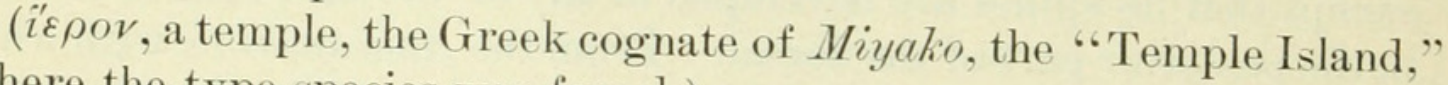
where the type species was found.)

I. HIERICHTHYS ENCRYPTES Jordan and Fowler, new species.

Head $6 \frac{1}{4}$; depth 10 ; D. 75 ; A. 64 ; P. 10 ; scales about 82 in a lateral series, about 30 in a vertical series in the middle of the body; head $1 \frac{1}{3}$ in the trunk; head and trunk a little less than twice in tail; depth of body $1 \frac{3}{5}$ in head; eye $1 \frac{1}{3}$ in snout, $4 \frac{3}{5}$ in head, 2 in maxillary; snout $3 \frac{1}{2}$ in head; maxillary $2 \frac{1}{3}$; pectorals about $3 \frac{1}{2}$.

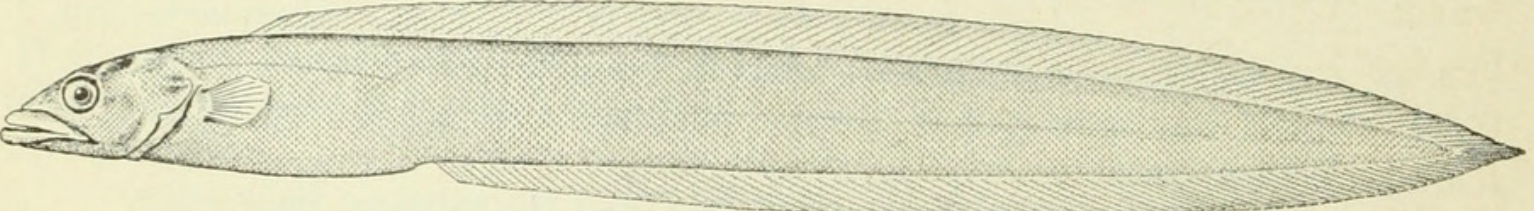

Fig. 1-HIERICHTHYS ENCRYPTES.

Body elongate, deep, and laterally compressed. Head greatly compressed laterally, so that it is little broader than the body; the snout sharply pointed and the lower jaw projecting; eyes lateral, rather close together; interorbital space a little more than half the eye, and convex; nostrils on the sides of the snout, the posterior very near the front margin of eye; maxillary long and reaching the middle of the eye; teeth moderately large, strong, and in a single series in each jaw; tongue long and pointed, free in front; lips rather broad and thick. Gill-openings very broad, the membrane forming a free fold over the isthmus. 
Head naked, except the cheeks and upper portion of the opercles, which, together with the body, are covered with small cycloid scales.

Dorsal, anal, and caudal continuous, the latter terminating in a point medianly, low, and of more or less uniform height; origin of dorsal over posterior part of pectoral; pectorals short. Lateral line short, straight, not distinct, running high, traceable as far as the origin of the anal.

Color in alcohol pale brown with traces of darker mottlings and blotches; fins darker brown; a brown spot on opercle.

Length, $4_{16}^{\frac{\pi}{6}}$ inches (112 millimeters).

Type.-No. 7120, Ichthyological Collections, Leland Stanford Junior University Museum. A single specimen, No. 613 of Ishikawa's catalogue, from the island of Myiako-shima in the Riu Kiu. Presented by the Imperial Museum of Tokyo.

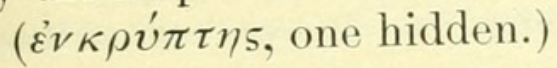

\section{Family II. ZOARCID E.}

\section{EELPOUTS.}

Body elongate, more or less eel-shaped, naked or covered with very small, embedded, cycloid scales; head large; mouth large, with conical teeth in jaws, and sometimes on vomer and palatines; bones of head unarmed. Gill-membranes broadly united to the isthmus, the gillopening reduced to a vertical slit; pseudobranchiæ present; gills 4, a slit behind the fourth. Dorsal and anal fins very long, of soft rays only, or the dorsal with a few spines in its posterior portion; vertical fins sometimes confluent around the tail; pectorals small; ventrals jugular, very small or wanting; if present, inserted behind the eye. Lateral line obsolete or little developed, sometimes bent downward behind pectorals, sometimes sending a branch on median line backward. Gill-rakers small; pyloric cæca rudimentary; vent not near head. Pseudobranchiæ present. Genera about 15 ; species 50 . Bottom fishes, chiefly of the Arctic and Antarctic seas; some of them, at least, are viviparous, and some descend to considerable depths. Dr. Gill thus enumerates the skeletal characters of the Zoarcidx:

Orbito-rostral portion of the cranium contracted and shorter than the posterior, the cranial eavity open in front, but bounded laterally by the expansion of the annectant parasphenoid and frontals, with the supraoccipital declivious and tectiform behind, the occipitals above inclined forward along the sides of the supraoccipital, and the exoccipital condyles distant, with the hypercoracoid foraminate about its center, and the hypocoracoid with an inferior process convergent to the proscapula. These characters are formulated from the skeleton of Zoarces anguillaris.

a. Zoarcinx: Dorsal fin low behind, some of its posterior rays short and spine like; ventrals small; scales present; teeth strong, conic, in jaws only; lateral line present along middle of side. 
aa. Dorsal fin continuous, of soft rays only

Zoarces, 2.

b. Lycodinx: Ventral fins present.

$c$. Vomer and palatines with teeth; lower jaws without barbels; dorsal fin without sculptured scutes at base; body slender, the depth 12 to 20 in the leugth; lateral line lateral in position; pectoral fin with rounded outlines, the lower rays not greatly produced................ Lycenchelys, 3 .

$b b$. Ventral fins entirely wanting.

d. Gymnelinx: Teeth moderate, nearly uniform on jaws, vomer, and palatines; body scaly; body compressed, not very slender; skull cavernous. Bothrocara, 4.

\section{ZOARCES Cuvier.}

Enchelyopus Klein, Ichthyologia, Missus, IV, 1747, p. 52 (non-binomial; not or BLOCH and SCHNEIDER = Rhinonemus GILL).

Zoarces Cuvier, Règne Animal, 2d ed., II, 1829, p. 175 (viviparus).

Zoarchus Swansson, Nat. Hist. Class'n Fishes, II, 1839, p. 283 (viviparus).

Enchelyopus Gill, Proc. Ac. Nat. Sci. Phila., 1863, p. 258 (viviparus; not of Bloch and SchneIDER).

Macrozoarces GiLL, Proc. Ac. Nat. Sci. Phila., 1863, p. 258 (anguillaris).

Body elongate, compressed, tapering posteriorly; head oblong, heavy, narrowed above, the profile decurved; mouth large; teeth strong, conic, bluntish in 2 series in the front of each jaw and 1 series on the sides; teeth in outer series larger; no teeth on vomer or palatines; dorsal fin very long, low, some of its posterior rays much lower than the others, developed as sharp spines; pectoral fins broad; ventrals jugular, of 3 or 4 soft rays; scales small, not imbricated, embedded in the skin; lateral line slender, lateral in position; size large; species viviparous. The American and Asiatic species (subgenus Macrozoarces) differ from the European type of Zoarces Cuvier, in the increased number of fin rays and vertebræ. In Zoarces viviparus (Linnæus), the European eelpout, the dorsal rays are about 100 , the anal about 85 , and the number of vertebræ is proportionally diminished.

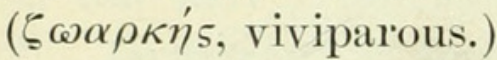

\section{ZOARCES ELONGATUS Kner.}

Zoarces sp. Kner, Neue Fische, Godeffroy Mus., 1865, p. 13; Decastris Bay, Manchuria.

Zoarces elongatus Kner, Sitzungsber. Akad. Wiss. Wien, 1868, p. 52, pl. vII, fig. 2; Okhotsk Sea (No. 1502 Wien. Mus.).

Head $6 \frac{1}{2}$ to $6 \frac{2}{3}$; depth 9 to $11 \frac{1}{2}$; D. 80 to $86-\mathrm{VII}$ to XVI-28 to 30 ; A. 95 to 98 , or more; P. 20 ; depth of body $1 \frac{2}{5}$ to $1 \frac{2}{3}$ in head; eye 4 to 7 ; snout $3 \frac{2}{3}$ to $5 \frac{1}{2}$; maxillary $2 \frac{1}{2}$ to $3 \frac{1}{3}$; pectoral $1 \frac{1}{4}$ to $1 \frac{1}{2}$; head $1 \frac{1}{5}$ to $1 \frac{1}{4}$ in trunk; head and trunk $1 \frac{1}{5}$ to $1 \frac{5}{6}$ in tail.

Body rather stout, compressed, elongate, and tapering to a point behind. Head oblong, compressed; snout blunt, very obtuse, convex, and rounded; eyes small, anterior, lateral in position, and much larger in the young; nostrils on the sides of the snout, small, and nearer the 
tip of the snout than the eye; lips very broad and fleshy; mouth large, the maxillary a little beyond the eye; teeth short, conical, rounded above, and in a single series in the upper, and in two series in the lower jaw in front; tongue very broad, thick, rounded, and little free in front. Gill-openings large, the isthmus broad, and the gillmembranes joined to it.

Head, pectorals, region around ventrals, dorsal and anal anteriorly, naked; scales of body very small, round, numerous, and cycloid; small scales upon the basal portions of the dorsal and anal posteriorly.

Dorsal beginning before the gill-opening, highest anteriorly, also higher than the anal, continuous with the caudal and anal, and with a small lower spinous portion, the origin of which is distant from the tip of the caudal about the length of the head; caudal small and pointed; pectoral broad, and the lower rays thick and fleshy; ventrals jugular, their insertion directly behind the margin of the preoperculum, and their length a trifle greater than the eye. Lateral line obsolete after the middle of the body.

Color in alcohol dark brown; edge of dorsal blackish brown, and the fin and back with about 18 deep-brown $\Lambda$-shaped marks, below which, on the sides, are a series of deep-brown blotches; a narrow streak from the eye backward; scales rather pale.

Length $12 \frac{1}{2}$ inches (31 millimeters).

The specimen from which the above description is taken was obtained at Iwani, in Shiribeshi, Hokkaido.

A specimen from Hakodate, in the museum at Hakodate, has 105 dorsal rays, the spinous part short; body with about 21 dark crossbands, $\Lambda$-shaped, and each with a spot below; pectorals nearly as long as head; ventrals very short; mouth large, extending to middle of eye.

In a specimen from Sagalin Island, presented by the Imperial Museum of Japan, the dorsal has 87-VI-28 rays and spines.

In our smallest example, from Tishima, Hokkaido, the spinous fin is very long, of XIV spines, farther from the tip of the tail than the length of the head, about the fifth, sixth, and seventh dorsal rays above, a deep-brown round spot; scales small; length $4 \frac{3}{4}$ inches (121 millimeters).

In spite of the variation exhibited in these specimens, they do not appear to us to justify specific distinction.

(elongatus; elongate.)

\section{LYCENCHELYS Gill.}

Lycenchelys Gill, Proc. Acad. Nat. Sci. Phila., 1884, p. 110 (muræna).

This genus contains small and very slender species, differing from Lycodes in the elongation of the body, the depth being from 10 to 20 times in the length. The lateral line is single and median in all known species. The genus is very close to Lycodes, but the position 
of the lateral line sufficiently defines it, especially in connection with the slender, eel-like form.

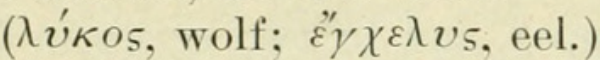

3. LYCENCHELYS PECILIMON Jordan and Fowler, new species.

Head $5 \frac{7}{8}$; depth 13; D. 107; A. 90; P. 17; depth of body $2 \frac{2}{5}$ in head; snout $4 \frac{2}{3}$; eye $3 \frac{4}{5}$; maxillary 2 ; pectoral $1 \frac{4}{5}$; head a little over 1 in trunk; head and trunk $1 \frac{7}{8}$ in tail.

Body elongate, the depth more or less uniform, greatest behind head, and the trunk tapering behind; compressed, and the width of the head greater than the greatest width of the body. Head elongate, oblong; snout rather blunt, obtuse, and convex above; eyes large, elongated, anterior, somewhat directed upward, very close together and greater than the snout; lips moderately broad; mouth large, the maxillary reaching a little beyond the posterior margin of the eye; teeth rather large, strong, pointed, and in a single series in each jaw,

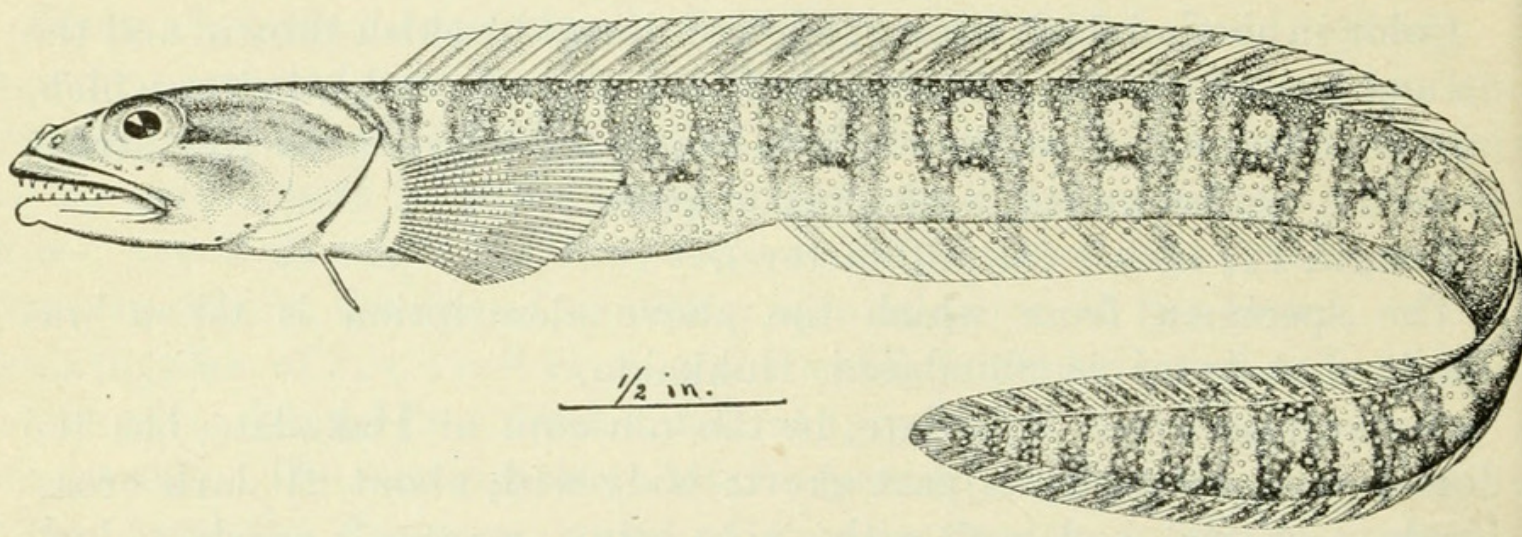

Fig. 2.-LyCENCHELYS PCECILIMON.

those of the upper jaw the larger; tongue thick, rounded, rather long, and not free in front. Gill-openings large, lateral, the membranes broadly united to the isthmus.

Head naked, also the nape, region about ventrals, and pectorals; body covered with small, round cycloid scales; the greater portion of the basal parts of the vertical fins posteriorly with small scales.

Dorsal almost over the base of the pectoral but posterior to the gillopening, and, like the anal, uniform in height to near the end of the tail, which is bluntly pointed; pectorals moderately broad and pointed; ventrals thoracic, rather slender, about equal to eye. Lateral line obsolete, a trace running along the middle of the sides.

Color in alcohol pale brown; sides with $11 \mathrm{H}$-shaped, deep-brown markings extending on the vertical fins, posteriorly these lose the middle and upper connecting bars and form about 8 deep-brown vertical bars; upper surface of head brownish, with several oblique bars across, one from the eye; lips blackish brown above; lower surface of the trunk, pectorals, ventrals, and anterior portion of anal pale. 
filaments; gill-rakers rather numerous and of moderate size; branchiostegals strong and 6 in number.

Head naked, the body covered with very small round cycloid scales.

Dorsal, anal, and caudal continuous, the latter terminating in a sharp point; origin of the dorsal a little behind the base of the pectoral; pectoral broad and pointed. Lateral line absent.

Color in alcohol plain brown, each scale on the body a little lighter; pectorals pale with their basal portions brownish; gill openings black inside.

Length, 19 inches (482 millimeters).

Type.-No. 50576, U. S. National Museum.

Locality, Station 3696, Sagami Bay, from the U. S. Fish Commission steamer Albatross dredgings.

Cotypes from Station 3696, in Sagami Bay, where they were dredged by the U. S. Fish Commission steamer Albatross, are in the Leland Stanford Junior University.

This species is very close to Bothrocara mollis of Bean, and is distinguished chiefly by the increased number of dorsal and anal rays, which are at least 112 without any of the caudal rays.

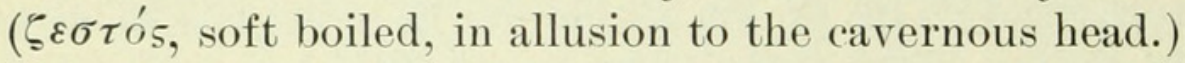

\section{Family III. CARAPID A.}

PEARL-FISHES.

Body elongate, compressed, tapering into a long and slender tail; no scales; teeth cardiform on jaws, vomer, and palatines; canine teeth often present; no barbels; lower jaw included; vent at the throat; gillmembranes somewhat united, free from the isthmus; no pseudobranchiæ; no pyloric cæca; vertical fins very low, confluent, without spines; no ventral fins; pectoral fins present or absent. Small shore fishes of tropical seas, often living in shells of mollusks, echinoderms, etc., being especially often commensal with the pearl oyster and with the larger Holothuria.

a. Pectoral fins present; no distinct caudal fin; gill-membranes connected anteriorly only Carapus, 5

5. CARAPUS Rafinesque.

Carapus Rafinesque, Indice. Ittiol. Siciliana, 1810, p. 57 (acus; originally intended for a Gymnotus).

Fierasfer Cuvier, Règne Anim., 1st. ed., II, 1817, p. 2393 (imberbe=acus).

Echiodon Thompson, Proc. Zool. Soc. Lond., 1837, p. 55 (drummondi).

Diaphasia Lowe, Proc. Zool. Soc. Lond., 1843, p. 92 (acus).

Oxybeles Richardson, Voy. Erebus and Terror, Fishes, 1846, p. 74 (homei).

Porobronchus Kaup, Ann. Mag. Nat. Hist., 1860, p. 272 (larva of Fierasfer acus). Carapus Gill, Proc. Ac. Nat. Sci. Phila., 1864, p. 152 (after Rafinesque, 1810). Vexillifer Gasco, Bull. Assoc. Nat. Med. Napoli, 1870, p. 59 (larva of Fierasfer acus).

Lefroyia Jones, Zoologist, IX, 1874, p. 3838 (bermudensis). 
Gill-membranes little connected, leaving the isthmus bare. No distinct caudal fin; pectoral fins developed. The species of this genus are not well known. and their characters and nomenclature are uncertain.

(Carapo, the Portuguese name of Gymnotus, with which genus this fish was supposed to be congeneric. In case the name Carapus is regarded as a synonym of Gymnotus the name Fierasfer should be restored.)

\section{CARAPUS KAGOSHIMANUS (Steindachner and Döderlein).}

Fierasfer kagoshimamus Steindachner and Döderlein, Fische Japans, IV, 1887, p. 27; Kagoshima.

Head $7 \frac{1}{2}$ (in total); depth $13 \frac{1}{2}$ (in total); eye $1 \frac{2}{3}$ in snout; $3 \frac{1}{3}$ in head; $2 \frac{1}{2}$ in interorbital space; head $2 \frac{1}{2}$ times as long as wide, and $1 \frac{2}{3}$ times as long as deep; pectoral $2 \frac{1}{3}$ in head. Small teeth in both jaws, on the vomer and palatines, the vomerine in a short band. Gill-openings broad; the united gill-membranes joined only to a small part of the isthmus. Vertical fins very low, the dorsal no more than $\frac{3}{4}$ the ength of the body; origin of anal below base of pectoral. Color uniform pink; top of head with fine black dots. Length $4 \frac{11}{3}$ inches (110 millimeters). Locality, harbor of Kagoshima. (Steindachner and Döderlein.)

Not seen by us.

\section{Family IV. OPHIDIIDA.}

\section{CUSK-EELS.}

Body elongate, compressed, more or less eel-shaped, usually covered with very small scales, which are not imbricated, but placed in oblique series at right angles with each other; head large; lower jaw included; ooth jaws, and usually vomer and palatines also, with villiform or cardiform teeth; premaxillaries protractile; gill-openings very wide; the gill-membranes separate, anteriorly narrowly joined to the isthmus behind the ventrals; pseudobranchiæ small. Gills 4, a slit behind the fourth; vent more or less posterior. Vertical fins lower, without spines, confluent around the tail; tail isocercal; ventral fins at the throat, each developed as a long forked barbel. Air bladder and pyloric cæca present. To this Dr. Gill adds also the following characters, shared more or less by related families: "Orbitorostral portion of cranium contracted and shorter than the posterior, the cranial cavity closed in part by the expansion and junction of the parasphenoid and frontals, the supraoccipital horizontal and cariniform posteriorly, the exoccipitals expanded backward and upward behind the supraoceipital, the exoccipital condyles contiguous, and with the hypercoracoid (scapula, Parker) fenestrate (or foraminate) about its center, and the aypocoracoid with its inferior process divergent from the proscapula." 
Genera 7, species about 25. Carnivorous fishes, found in most warm seas, some of them descending to considerable depths, the group espe cially well represented in tropical America.

a. Head scaleless; scales of body rudimentary, scarcely embedded; opercle ending in a sharp spine, concealed by the skin; air bladder short and broad, with a large foramen behind

Otophidium, 6

\section{OTOPHIDIUM Gill.}

Otophidium GiLl, in Jordan, Cat. Fish. North Amer., 1885, p. 126 (omostigma).

This genus differs from Ophidion in the form of the air bladder, which is short and thick and with a large foramen. The opercle ends in a concealed spine as in Chilara.

(oйs, ear; Ophidium.)

6. OTOPHIDIUM ASIRO Jordan and Fowler, new species.

Head 5 ; depth $6 \frac{5}{6}$; D. 155 ; A. 125 ; P. 25 ; eye 4 in head, $2 \frac{1}{5}$ in maxillary; snout 5 in head, $2 \frac{2}{3}$ in maxillary; maxillary $1 \frac{5}{6}$ in head; pectoral $2 \frac{1}{3}$; depth of head $1 \frac{1}{3}$ in its length; head 1 in trunk; head and trunk $1 \frac{2}{5}$ in tail.

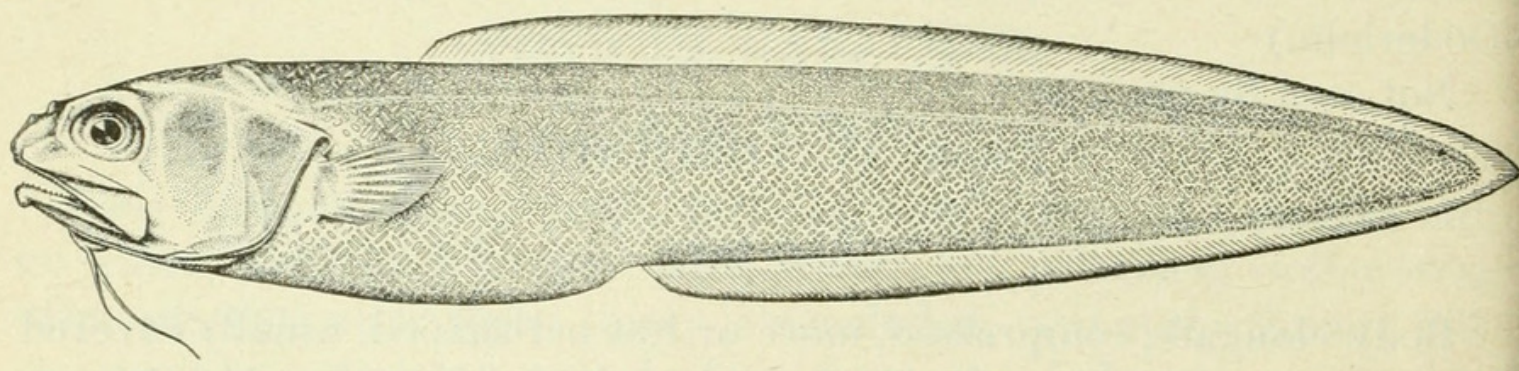

Fig. 4.-OTOPHIDIUM Asiro.

Body elongate, deep and compressed, the tail tapering to a point. Head compressed, about as broad as body in front; snout rather bluntly rounded; eye large, its posterior edge much nearer tip of snout than gill-opening; maxillary reaching a little beyond posterior margin of eye, and its distal extremity expanded so that it is equal to $\frac{1}{3}$ its length; nostrils rather smali directly in front of the eye; teeth in rather broad bands in the jaws, and with an outer enlarged series; vomerine and palatine teeth conical; tongue rather slender, pointed, and adnate to the floor of the mouth. Gill-openings very large, joined to the isthmus; pseudobranchiæ of a few small filaments; gill-rakers large, $3+3$ in the first arch. Opercular spine large, covered by skin.

Head naked; body covered more or less with elongated small cycloid scales.

Dorsal, anal, and caudal continuous, the latter terminating in a point; origin of the dorsal before the tip of the pectoral; pectoral rather small, its margin rather pointed; ventrals jugular, of two rather long 
ilaments, the longest about $1 \frac{1}{2}$ in head, and their bases anterior to the niddle of the eye. Lateral line superior, on the back, and concurrent vith its dorsal outline to the base of the caudal. Air bladder large, hick, and short, with a large foramen.

Color in alcohol plain uniform brown, the edges of the caudal, lorsal, and anal blackish brown; opercles brassy.

Length, $8 \frac{1}{32}$ inches (204 millimeters).

Type.-No. 7123, Ichthyological collections, Leland Stanford Junior Jniversity Museum. Locality, Misaki; presented by the Imperial University of Tokyo.

(asiro, the vernacular name.)

\section{Family V. BROTULIDA.}

Body elongate, compressed, regularly tapering behind, the tail genrally subtruncate at base of caudal fin, not isocercal; vent submedian; cales cycloid and minute, embedded in the lax skin, which more or less nvelopes the fins, sometimes wanting; mouth large, with teeth usually n broad bands on jaws, vomer, and palatines; gill-openings very large, he membranes mostly free from the isthmus; vertical fins united or ontinuous at base of caudal; dorsal fin beginning not far from nape; audal narrow or pointed; ventral fins small, few-rayed, attached to he humeral arch and more or less in advance of pectoral. Pyloric rea few (1 or 2), rarely obsolete or in increased number (12); maxllaries generally enlarged behind and produced toward the upper ngle. Pseudobranchiæ small or wanting, hypercoracoid with the sual foramen, as in Blennioid fishes. These fishes are closely related o Zoarcidx. In spite of curious external resemblances to the Gadidx, heir affinities are decidedly with the Blennioid forms rather than with he latter. Species largely of the depths of the sea; 2 species in Cuba legenerated into blind cave fishes.

Brotulinx: Snout and lower jaw each with about 3 long barbels; vertical fins united; ventrals close together, each of two rays divided at the tips .. Brotula, 7 Snout and lower jaw without barbels.

b. Bythitinx: Caudal not differentiated, on a distinct caudal peduncle; eyes well developed; body scaly; ventrals inserted on the isthmus near the humeral symphysis; deep-sea species.

c. Pectoral fins normal, the lower rays not elongate.

d. Ventral fins close together, each of a single undivided ray; lateral line simple, obsolete behind; preopercle unarmed; opercle with a single spine.

$e$. Head naked, covered with loose skin, with fine papillæ; bones of skull

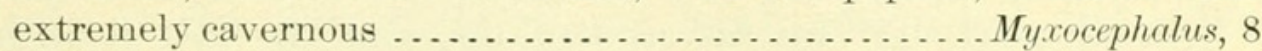

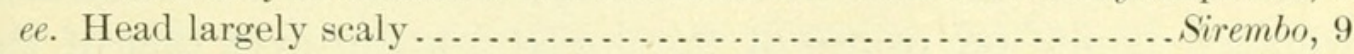

dd. Ventral fins of two rays each, separated at tip.

$f$. Lateral line simple, indistinct posteriorly.

g. Preopercle unarmed; head large.

h. Ventral fins well separated, rather long ............ Bassogigas, 10

gg. Preopercle with 2 spines; head extremely scaly ........ Watasea, 11

Proc. N. M. vol. $\mathrm{xxv}-02-48$ 
.ggg. Preopercle with 3 spines; head naked anteriorly ...Hoplobrotula, 12 ff. Lateral line represented by three rows of pores, dorsal, lateral, and ventral; head with numerous spines and mucous pores; opercular spine straight ............................ Porogadus, 13

$c c$. Pectoral with the lower rays free, produced beyond the upper; preopercle with 3 spines; ventrals simple, well separated ............Pteroidonus, 14

\section{BROTULA Cuvier.}

Brotula Cuvier, Règne Animal, 2d ed., II, 1829, p. 296 (barbata).

Body elongate, compressed, covered with minute, smooth scales; eye moderate; mouth medium, with villiform teeth on jaws, vomer, and palatines; lower jaw included; each jaw with 3 barbels on each side. Dorsal fin long and low, the dorsal and anal joined to the caudal. Ventral fins close together, very slender, each of two rays separated at the tip. Eight branchiostegals. Air bladder large, with 2 horns posteriorly. One pyloric cæcum. Vertebræ $16+39=55$. Tropical.

(brotula, Spanish name of Brotula barbata.)

\section{BROTULA MULTIBARBATA Schlegel.}

\section{ITACHI-UWO (WEASEL-FISH); UMINAMAZU (SEA CAT-FISH).}

Brotula multibarbata Schlegel, Fauna Japonica, Poiss., 1847, p. 251, pl. III, fig. 2; Nagasaki.-Günther, Cat. Fish., IV, 1862, p. 371; Japan, Celebes, Amboina, Buru.-Ishikawa, Prel. Cat., 1897, p. 26; Tokyo.-Steindachner, Reise H. M. S. Aurora, 1898, p. 216; Kobe (good description).

Brotula japonica Sterndachner and Dönerlein, Fische Japans, IV, 1887, p. 24; Tokyo.

Head, 5 (in total); depth. 4 to $4 \frac{1}{2}$ (in total); D., C., and A. 186; P. 22 ; V. 1; B. 8 ; Cæc. pylor. 2 ; interorbital space, $\frac{3}{4}$ the eye; ventral, $\frac{2}{3}$ of head.

Body elongate, the tail very compressed and terminating in a point; swelling of trunk behind pectorals somewhat more than half the depth of the body. Head rounded above; eye equal to snout; snout with a slight projection above in front; maxillary extends to the posterior border of the eye; jaws about equal, or the lower a little shorter; a band of velvety teeth in jaws, on vomer, and on palatines; opercular margin pointed behind; operculum with a strong spine posteriorly; mandibular barbels 6 , the longest about $\frac{1}{3}$ the head; 6 superior barbels, these $\frac{1}{3}$ longer than those below.

Body and head covered with small, smooth, round scales, the surface finely granulated.

Dorsal, anal, and caudal continuous, and the last terminating in a rounded point; the origin of the dorsal is about over that of the pectoral; pectorals inferior, rounded, hardly half the head; ventrals close together, of 2 filaments united, the inner $\frac{1}{3}$ shorter than the outer. Vent in about $\frac{3}{7}$ the total length. Lateral line superior, with a distinct curve anteriorly. 
General color when fresh reddish brown; abdomen paler; pectorals olivaceous; all the fins bordered with whitish; lips, barbels, and ventrals somewhat reddish; iris grayish. Shimabara. (Schlegel.)

This species is apparently rare in Japan; no specimens being found in our collections. It was described by Schlegel from Shimabara, near Nagasaki, by Döderlein from off Tokyo, and by Steindachner from Kobe.

(multum, many; barbatus, bearded.)

8. MYXOCEPHALUS Steindachner and Döderlein.

Myxocephalus Steindachner and Döderlein, Fische Japans, IV, 1887, p. 25. (japonicus).

Body short, rather deep, greatly compressed, and ending in a point behind; covered with moderate-sized, smooth, and elongate scales. Head very large, broad, thick, rounded, without scales, covered with soft loose skin beset with small, short, shred-like filaments or papillæ; the bones with large mucous cavities opening by pores. Eye small, mouth rather large; teeth villiform on vomer, palatines, and in jaws; no barbels; preopercle unarmed; opercle with a spine. Gill-openings very large and the membranes narrowly free over the isthmus. Dorsal and anal in a broad basal membrane in front. Ventrals close together below opercles, each of a single ray. Lateral line arched till over vent, then straight to the base of the caudal. No pyloric cæca. Pseudobranchiæ rudimentary or absent.

( $\mu v^{\prime} \xi o 5$, mullet; $\kappa \varepsilon \phi \alpha \lambda \eta \dot{\eta}$, head.)

\section{MYXOCEPHALUS JAPONICUS Steindachner and Döderlein.}

ITACHI (MINK OR WEASEL).

Myxocephalus japonicus Steindachner and Döderlein, Fische Japans, IV, 1887, p. 25; off Tokyo.

Head $3 \frac{3}{4}$; depth about 4; D. 134; A. 100; P. 31; V. 1; greatest depth of body $1 \frac{1}{8}$ in the head; breadth of head $1 \frac{1}{4}$; depth of head about $1 \frac{1}{4}$; interorbital space, 3 ; width of mouth, $2 \frac{1}{3}$; maxillary, $2 \frac{1}{2}$; snout 5; eye 7; eye, $1 \frac{1}{2}$ in snout, 3 in maxillary, $2 \frac{1}{2}$ in interorbital space; pectoral $1 \frac{1}{2}$ in head; ventral, 2.

Body greatly compressed, rather short and deep, the tail tapering to a point. Head very large, broad, thick, and oblong; snout very blunt, obtuse, broad, and rounded above; eye small, lateral, its posterior margin at the first third of the head; preorbital and infraorbitals broad; posterior nostrils large, directly in front of the eye; anterior nostrils in a large tube near the tip of the snout; a large pore exterior to the anterior nostrils on each side, another on each side of the head above; gill-rakers large, thick, more or less variable and about $\frac{5}{15}$; a slit after the fourth gill-arch. 
Head naked, the rest of the body covered with elongate smooth cycloid scales. Along the bases of the dorsal and anal anteriorly a rather thin broad membrane concealing the bases of the fin rays.

Dorsal originating a little behind the base of the pectoral, confluent with the anal and caudal, the latter terminating in a sharp point; pectoral long, its base thick, broad, and the middle rays forming a blunt angle; nostrils close together and situated a little posterior to the posterior margin of the preoperculum. Lateral line high in front, curved till about over the vent, when it runs medianly along the sides to the base of the caudal.

Color in alcohol uniform dark brown; pectorals, dorsal, caudal, anal, and inside of gill-opening black; the filaments on the head blackish; lower surface of the head slightly pale.

Total length, $15 \frac{3}{4}$ inches (400 millimeters).

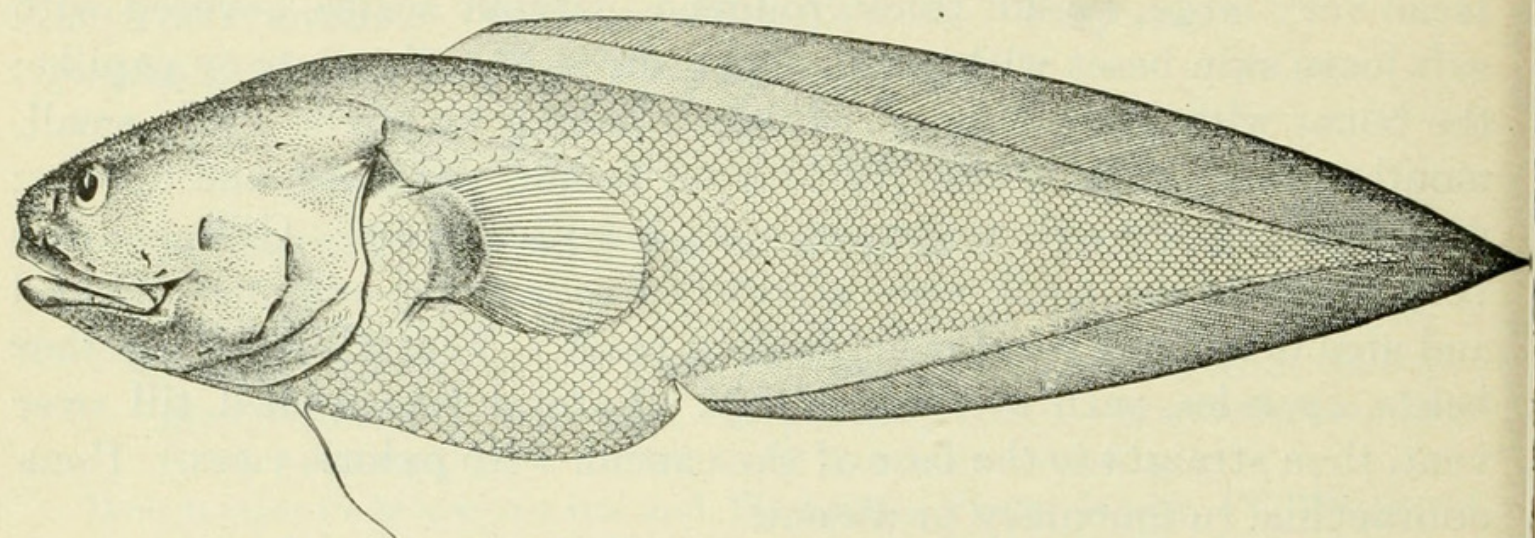

Fig. 5.-MYXOCEPHALUS JAPONICUS.

This species is known to us from the specimen described above, collected at Uraga, near Misaki, by Capt. Alan Owston. It differs from Steindachner's description somewhat, especially in the presence of rudimentary or small pseudobranchiæ, slightly broader head, and greater number of fin rays.

\section{SIREMBO Bleeker.}

Sirembo Bleeker, Act. Soc. Sci. Indo. Nederl., III, Japan, IV, 1858, p. 22 (imberbis).

Brotella Kaup, Wiegmann's Archiv, 1858, p. 92 (imberbis).

Body elongate, covered with very small scales. Lateral line simple, well developed anteriorly, indistinct behind. Eye moderate, vertical fins united; ventral fins each reduced to a single filament, the two inserted close together, on the humeral symphysis. Jaws, vomer, and palatines with bands of villiform teeth. Lower jaw included. Snout without barbels. Air-bladder present. Preopercle unarmed; opercle with spines. Shore fishes of Japan.

(Name unexplained.) 


\section{SIREMBO IMBERBIS Schlegel.}

UMIDOJO (SEA LOACH).

Brotula imberbis Schlegel, Fauna Japonica, Poiss., 1847, pl. 253, p. III, fig. 3; Nagasaki.

Sirembo imberbis Bleeker, Act. Soc. Sci. Indo Nederl., III, 1857, Japan, IV, p. 22.

Head $4 \frac{7}{8}$; depth $5 \frac{3}{4}$; D. about 90 ; A. about 67 ; P. 22; V. 1; depth of body $1 \frac{1}{5}$ in head; eye 4 in head, 2 in maxillary; snout 5 in head, $2 \frac{1}{2}$ in maxillary; pectoral $1 \frac{4}{5}$ in head; ventrals $1 \frac{1}{5}$; head 1 in trunk; head and trunk about $1 \frac{1}{6}$ in tail.

Body oblong, greatly compressed, and the tail tapering to a point. Head oblong, compressed; snout truncate, rounded, blunt, less than the eye; eye superior, somewhat elongate, its posterior margin much nearer the snout than the gill-opening; mouth large, the maxillary expanded and reaching a little beyond the eye; expanded extremity of maxillary with its posterior edge concave and its breadth at this point about two-thirds the eye; nostrils lateral, in front of eye on the snout; interorbital space a little less than eye, and almost flat; teeth in villiform bands in the jaws and on vomer and palatines; tongue very thick, pointed, and little free in front; infraorbital rather narrow; lips rather fleshy. Gill-openings large, the membranes not united, and the isthmus narrow; pseudobranchiæ rather small; gill-rakers $.5+15$, and only those on the upper part of the arch below the bend elongated and thick, the others small, rounded, and rudimentary.

The body covered with rather large, round scales. Head almost entirely scaled.

Dorsal beginning behind the pectoral and, like the anal, rather high; dorsal, anal, and caudal confiuent, the latter ending in a sharp point; pectoral rather broad, pointed behind; ventrals jugular, each of a single ray and with their bases close together below the posterior part of the eye. Lateral line superior and concurrent with the back to the base of the caudal.

Color in alcohol brown, darker above, paler beneath, and silvery; opercles with a dark spot; pale longitudinal stripes on the sides, the first from the snout across the upper part of the eye, so that a dark stripe runs below this through the eye, then below this latter another white stripe from the base of the pectoral above, and, finally, below this another darker one, which is indistinct; along the base of the dorsal are a number of dark-brown blotches, and another series is also seen along the lateral line; bases of dorsal, anal, and caudal very pale; dorsal margined broadly with blackish, the tail grayish, the anal with a narrow white border, and also with a blackish marginal longitudinal band; pectorals and ventrals pale.

Length $9 \frac{1}{16}$ inches ( 230 millimeters).

Described from Nagasaki examples. 
This species occurs at moderate depths and is common in southern Japan. Our numerous specimens are from Tokyo, Misaki, Wakanoura, and Nagasaki. At Nagasaki it is especially abundant, and is by no means a deep-water fish.

(imberbis, beardless.)

\section{BASSOGIGAS Gill.}

Bassogigas Gith, in Goode and Bean, Oceanic Ichthyology, 1895, p. 329 (grandis).

Body elongate, compressed, covered with thick, heavy skin, which obscures all the angles of the skull. Scales small, covering the head completely. Lateral line indistinct behind. Eye moderate. Vertical fins united about the tail; ventral fins well separated, each one a bifid filament. Snout slightly produced, without barbels, the lower jaw slightly included. Villiform teeth on jaws, vomer, and palatines, the vomerine patch V-shaped. Opercle with a long sharp spine; preopercle unarmed. Air bladder present; pseudobranchiæ small. Deep seas, both Atlantic and Pacific.

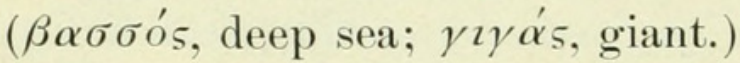

Io. BASSOGIGAS GRANDIS Günther.

Sirembo grandis Günther, Ann. Mag. Nat. Hist., XX, 1877, p. 437; near Yokohama in deep water.

Neobythites grandis Günther, Deep Sea Fishes, Challenger, p. 100, pl. xxı, fig. A; near Yokohama.

Head rather short and broad, with obtuse snout overlapping the lower jaw; eye small, about $\frac{1}{3}$ the length of snout and $\frac{1}{11}$ the head; mouth rather wide, the maxillary extending to behind the eye; barbels none; teeth of jaws, vomer, and palatines in villiform bands; vomerine teeth form a triangular patch much broader than long; width of palatine band exceeds that of intermaxillary; a deep groove in the skin descends from the anterior nostril toward the maxillary and reascends toward the median line of the extremity of the snout, cutting off an anterior lobe as in some sciænoids; several pores leading into the muciferous system are hidden in the groove; a few small open pores near the symphysis of the mandible; nostrils gaping, oval openings, of which the anterior is surrounded by a membranous wall; preoperculum crescent shaped, without any armature; operculum with a strong spine above.

Scales minute; also the entire head, even the space between the nostrils, covered with minute scales.

Dorsal, like the anal, enveloped in a thick, scaly skin; it begins with short rays above the middle of the pectoral; pectoral rounded, broad, and remarkably short, about half as long as the head; ventrals inserted below the angle of the preoperculum: each ventral filament is bifid, the inner part being the longer; distance of vent from root of pectoral 
more than the length of the head. Lateral line indistinct for the greater part of the course.

Color brown, darker behind, lighter in front; fins blackish, cavity of mouth gray, peritoneum black. Total length $29 \frac{1}{2}$ inches; head $5 \frac{3}{4}$ inches; ventral filament 3 inches; snout to vent $12 \frac{1}{2}$ inches.

Locality, south of Tokyo, near Yokohama, at Station 237 (Challenger) in 1,875 fathoms. (Günther.) Not taken by us.

(Grandis, great.)

11. WAtAsEA Jordan and Snyder.

Watasea Jordan and Snyder, Proc. U. S. Nat. Mus., 1900, p. 765 (sivicola).

Body elongate and completely covered with small scales. Head scaled, blunt; eye moderate; the jaws equal; no barbels; teeth in jaws, vomer, and palatines minute, blunt, and in bands; preopercle with two spines; vertical fins united, the caudal pointed; pectorals accutely rounded; ventrals close together, each of two rays; eight branchiostegals.

(Named for Sho Watase, professor of Animal Morphology in the Imperial University of Tokyo.)

ir. WATASEA SIVICOLA Jordan and Snyder.

Watasea sivicola Jordan and Snyder, Proc. U. S. Nat. Mus., 1900, p. 765, pl. xxxviI; Misaki, Yokohama.

Head, $4 \frac{3}{4}$; depth, $5 \frac{3}{4}$; D. $94 ;$ A. 74 ; scales in lateral line about 100 ; scales between middle of base of dorsal and lateral line, 8; between origin of dorsal and lateral line, 11; between lateral line and anal, about 25; head as long as trunk; head and trunk, $1 \frac{2}{5}$ in tail; depth of body, $1 \frac{1}{6}$ in head; eye, $4 \frac{3}{4}$; snout, 6 ; maxillary, 2 ; interorbital space, $4 \frac{2}{3}$; width of head at maxillaries, $2 \frac{4}{5}$; pectoral, $1 \frac{3}{5}$; ventral, $1 \frac{1}{3}$.

Body elongate, greatly compressed, its greatest width much less than the breadth of the head, and tapering into a pointed tail. Head oblong, compressed; snout very blunt, truncate; jaws equal; eyes small, elongate, lateral, and its posterior margin about the first $\frac{2}{5}$ of the head; maxillary very large, extending far beyond the eye, and its distal expanded moiety $1 \frac{1}{3}$ in the eye, and its posterior margin concave; supplemental maxillary well developed and concealed by the infraorbitals, which are much less than the eye diameter; teeth in jaws, on vomer and palatines in broad villiform bands; lips thin; tongue rather broad, thick, pointed, and little free in front; nostrils rather large and the posterior the larger; upper profile straight from snout to occiput; preoperculum with 2 strong, broad, sharp spines pointed back; opercle with a strong spine above, directed backward and slightly inclined downward; head with mucous cavities and pores; interorbital space convex, its width much greater than snout. Gill-opening very large, 
the isthmus narrow, and the membrane joined to it under the eye; a band of villiform teeth along the floor of the pharynx, beginning on the tongue and the pharyngobranchials above, forming a toothed area posteriorly similar to those below; pseudobranchiæ small; gill-rakers $5+11$ on first arch, somewhat thick, blunt, and long; branchiostegals, 8 .

Head and body covered with elongated, smooth, cycloid scales; bases of pectoral and dorsal rays with small scales.

Dorsal, anal, and caudal confluent, the latter ending in a point; the membrane at base of the fins not fleshy; dorsal beginning about $\frac{1}{4}$ the length of the head from its posterior end; pectoral short, pointed, and only reaching about $\frac{3}{5}$ the space between its own origin and the vent; ventrals only separated by a narrow space, inserted about midway between the posterior edge of maxillary and tip of lower preopercular spine; the inner filament the longer and reaching midway in the space between its base and the vent, the undivided basal portions of ventrals equal to $1 \frac{1}{3}$ eye diameters. Lateral line running along the upper third of the body and disappearing at a point about $\frac{1}{2}$ the length of the head from the base of the caudal.

Color in alcohol plumbeous gray, and more or less silvery below.

Length, $9 \frac{3}{16}$ inches (234 millimeters).

This description from the type No. 6375, Ichthyological Collections, Leland Stanford Junior University Museum. Locality, Misaki, in Sagami. Taken in deep water.

Another is in the U. S. National Museum (No. 49707), taken by Mr. P. L. Jouy off Yokohama.

(Kuro Shiwo, the Black Current, colo, to inhabit.)

\section{HOPLOBROTULA Gill.}

Hoplobrotuia GiLt, Proc. Ac. Nat. Sci. Phila., 1863, p. 253 (armata).

This genus differs from Watasea and Sirembo in having three strong spines on the preopercle. Maxillary and anterior parts of head naked; posterior upper part of maxillary free from the suborbital; ventral fins bifid; lateral line simple; well developed anteriorly.

(ó $\pi$ 入ov, armature; Brotula.)

\section{HOPLOBROTULA ARMATA (Schlegel).}

Brotula armata Schlegel, Fauna Japonica, 1847, p. 255; Nagasaki.

Sirembo armata Steindachner and Dönerlein, Fische Japans, IV, 1887, p. 24; Tokyo.

Hoplobrotula armata JoRdan and SNyder, Proc. U. S. Nat. Mus., 1900, p. 767, pl. xxxvin; Nanaura in Boshu.

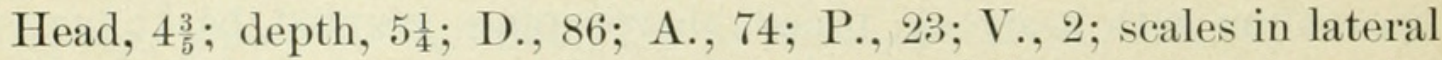
series, 112; scales between base of dorsal and lateral line, 9 ; scales between lateral line and anal, 27; head and trunk, $1 \frac{1}{2}$ in tail; depth of head, $1 \frac{1}{3}$ in its length; width of head, $1 \frac{3}{4}$ in its length; eye, 5 in head; 
snout, $4 \frac{1}{6}$; maxillary, 2 ; interorbital space, 4 ; width of mouth at maxillaries, $1 \frac{7}{8}$; pectoral, $1 \frac{2}{5}$; ventrals, $1 \frac{3}{5}$.

Body elongate, greatly compressed, its greatest width much less than the breadth of the head, and tapering into a pointed tail. Head oblong, compressed; snout very blunt, truncate; jaws equal; eye small, elongate, lateral and its posterior margin about the first $\frac{2}{5}$ of the length of the head; maxillary very large, extending far beyond eye, its distal expanded moiety equal to snout, and the posterior edge slightly emarginate; supplemental maxillary well developed and not entirely slipping under the infraorbitals, which are not as broad as the eye diameter; teeth in rather broad, rough, villiform bands on vomer and palatines and in the jaws; lips fleshy and more or less papillose or shredded; tongue very broad, thick, pointed, and hardly free in front; nostrils in front of eye; upper profile straight from snout to occiput; preoperculum with 3 strong spines protruding through the skin, the lower one pointing downward and the other 2 pointing downward and backward; opercle with a strong spine above, bent down and backward; a number of mucous pores on head, several on opercles above, on the mandible, orbitals, and 2 large ones at the edge of the snout in front of nostrils; interorbital space convex, its width equal to snout. Gill-opening very large, the isthmus long and narrow, and the membrane thick, united directly below front of eye; a toothed area extending from near tip of tongue to posterior part of pharynx, the roof of which is furnished with a toothed surface similar to those of the jaws; pseudobranchiæ very small; gill-rakers $5+16$, thick, short, those of the upper limb and all but 5 of the lower reduced to mere rounded elevations, the other short and flat; branchiostegals, 8 .

Head naked, except opercles, the sides of head above, and preopercles, which are covered with rather large cycloid scales; scales on body similar, becoming elongated at the end of the tail.

Dorsal, anal, and caudal confluent, the latter ending in a point; the membrane at base of the fins rather fleshy; dorsal beginning above over the first third of pectoral, or at a distance behind head equal to one-fourth the latter's length; pectoral long, pointed, and reaching vent; ventrals divided to within a short distance of their base, the remaining basal space not divided equal to an eye in diameter; the inner ventral ray the longest and not quite to the base of pectoral; the ventrals are inserted below the anterior portion of the eye. Lateral line superior, approaching nearer to the back posteriorly, and becoming obsolete at a distance from the tip of the caudal equal to three-fourths the length of the head.

Color in alcohol uniform pale brown overlaid with silvery, the dorsal and anal becoming deep brown posteriorly like the caudal, which is entirely the same color. 
Length, $15 \frac{7}{8}$ inches (403 millimeters).

This description from the specimen described by Jordan and Snyder, obtained at Nanaura, in Boshu, near Misaki, and presented by the Imperial University of Japan to the Stanford University Collection.

(armatus, armed.)

\section{POROGADUS Goode and Bean.}

Porogadus Goode and Bean, Proc. U. S. Nat. Mus., VIII, 1885, p. 602 (miles).

Body brotuliform, much compressed; head with numerous spines on interorbital space, 2 pairs on the shoulders, 1 at angle of operculum, and a double series on angle of preoperculum; head with numerous mucous pores, as in Bassozetus; mouth large; snout moderate, not projecting much beyond the upper jaw; jaws nearly equal in front; teeth in villiform bands in jaws and on vomer and palatines; barbel none; gill-openings wide, membranes narrowly united, not attached to the isthmus; gills 4; gill laminæ short; gill-rakers moderate, numerous; pseudobranchiæ absent; caudal fin of few rays, on a very narrow base, not prolonged, scarcely differentiated from the vertical fins; dorsal and anal fins well developed; pectorals simple, moderate; each ventral a single bifid ray close to the humeral symphysis; branchiostegals 8; scales small; lateral line apparently triple or replaced by 3 series of pores-1 close to ventral outline, 1 median, and another along base of dorsal.

( $\pi$ ópos, pore; Gadus, the cod fish.)

13. POROGADUS GÜNTHERI Jordan and Fowler, new species.

Head, $6 \frac{3}{4}$; depth, $11 \frac{2}{3}$; head and trunk, $3 \frac{3}{5}$ in tail; depth of body, $1 \frac{2}{3}$ in head; eye, 6 ; snout, $3 \frac{1}{3}$; maxillary, $1 \frac{3}{4}$; interorbital space, $3 \frac{1}{3}$; width between maxillaries, $2 \frac{3}{5}$; pectoral, $1 \frac{4}{5}$; ventral, $1 \frac{2}{3}$.

Body very elongate, compressed so that it is not as broad as the head, and gradually tapering posteriorly into a long, slender tail. Head about equal to trunk, compressed, oblong; snout broad, convex above, and much greater than eye; eye lateral, its position much before middle of head; jaws equal, mouth broad, the maxillary expanded distally, its posterior edge concave, and equal to the eye, and projecting far beyond; supplemental maxillary well developed and not concealed by the orbitals; teeth in narrow, villiform bands in jaws, on vomer, and on palatines; lips thin; tongue small, thick, pointed, and free in front; anterior nostrils not evident, the posterior very large, in front of eye; upper profile straight from snout to occiput; head with many spines; opercular spine sharp; gill-opening very large, the membrane narrowly free over the narrow isthmus; a narrow median band of villiform teeth along the floor of the pharynx and the roof also with an area of villiform teeth; pseudobranchiæ reduced to 2 
small filaments; gill-rakers, $5+24$ on the first arch and only 19 on the lower part of the arch, long, attenuated, and well developed; branchiostegals, 8 .

Head and body covered with small, smooth cycloid scales, perhaps 200 in a lateral series.

Dorsal, anal, and caudal confluent, the latter ending in a point; the dorsal beginning a little behind the base of pectoral; pectoral small, pointed, and reaching more than half the distance in space between its base and vent; ventrals close together, each of two filaments and inserted below the head nearer the base of the pectoral than the extremity of the maxillary; undivided basal portion of the ventrals equal to two-thirds the eye. Lateral lines of large pores rather widely separated, running along the base of the dorsal, the sides medianly, the sides of the abdomen, and the base of the anal below.

Color in alcohol for the greater part brown, the sides and lower part of the head together with the abdomen black; top of the head, snout and orbital region gray-white.

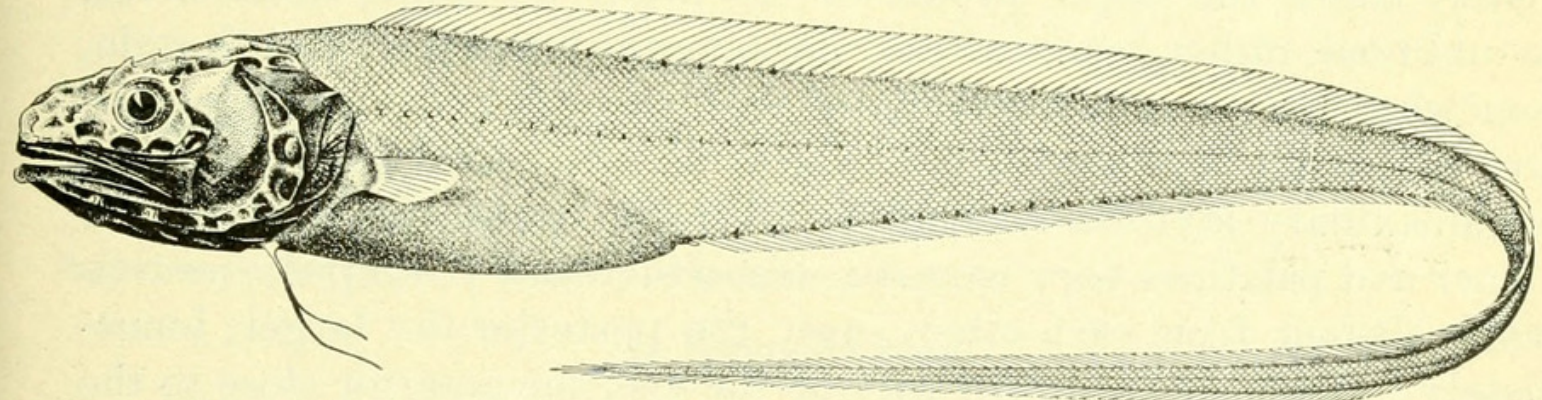

Fig. 6.-Porogadus gÜNTHERT.

Length, $8_{16} \frac{5}{16}$ inches (211 millimeters).

Type.-No. 50577, U. S. National Museum.

Locality in Sagami Bay, at Station No. 3696, where it was dredged in 501 to 749 fathoms by the U. S. Fish Commission steamer Albatross.

Cotypes No. 7124 are in the Ichthyological Collections, Leland Stanford Junır University

(Named for Dr. Albert Günther.)

\section{PTEROIDONUS Guinther.}

Pteroidonus Günther, Deep-Sea Fishes Challenger, 1887, p. 106 (quinquarius).

Body elongate, compressed, covered with small scales. Head oblong, thick, covered with scales; eye small; snout broad, with rounded profile, including lower jaw, and without barbel; mouth wide, bands of villiform teeth in the jaws, on vomer, and palatines; operculum with a straight spıne; preoperculum armed. Eight branchiostegals; gilllaminæ rather short; gill rakers rather long, lanceolate, and widely set; pseudobranchiæ none. Vertical fins united, but the narrow caudal 
projecting beyond the short anal and dorsal rays; the lower pectoral rays are incompletely united with the upper part of the fin and are prolonged; ventrals reduced to a simple filament, inserted behind the humeral symphysis, and somewhat distant from each other. Lateral line incomplete, close to the dorsal profile. A true deep-sea form.

(Pterois, Onus.)

\section{PTEROIDONUS QUINQUARIUS Günther.}

Pteroidonus quinquarius GüNther, Deep-Sea Fishes Challenger, 1887, p. 106; Deep Sea of Japan, Station 235, 565 fathoms.

D. 99 ; A. 87 ; P. $15-5$; V. 1 ; C. 5 ; B. 8 ; 35 scales transversely above vent; eye, 7 in head; caudal, $7 \frac{1}{2}$.

Body elongate, compressed, its depth being less than the length of the head, which equals the distance between the vent and the root of the pectoral fin. Head not much deeper than broad, its depth equal to the length of its postorbital portion and flat above; eye small, without orbital fold, much shorter than snout, lateral, and situated immediately below the upper profile of the head; no spines about orbit; snout broad, rather depressed, overlapping the lower jaw; mouth wide, somewhat oblique, the much-dilated posterior extremity of the maxillary extending backward beyond the orbit; preorbital region narrow, inframaxillary styliform; teeth in villiform bands, the bands of the vomer and palatines very narrow; vomerine band $\Lambda$-shaped; nostrils rather distant from each other, open, the posterior the larger, immediately in front of the upper part of the eye, the anterior close to the end of the snout; the interorbital space more than twice the eye; preoperculum with a rounded angle which is armed with 3 very short and weak spines; opercular spine moderately strong and straight; the bones of the head are thin, with shallow muciferous cavities. Gill-membranes entirely separate.

Nearly the entire head, even the dilated extremity of the maxillary and the glossohyal region, are covered with small scales; the scales are small, thin, smooth, and adherent.

Dorsal begins a short distance behind root of pectoral, rather low, the rays inclosed in a scaly skin at base, and has its last and shortest rays connected with caudal by a membrane; anal similar to dorsal but lower; pectoral with broad base, elongate, posterior margin rounded, and as long as head without snout; the 5 detached rays are somewhat stronger than the other rays; they form at the base one continuous series with the remainder of the fin, and therefore do not seem to possess a separate action; the uppermost ray is the longest, not quite twice as long as the fin, the others gradually decreasing in length; ventrals very feeble simple filaments, only half as long as the pectoral, somewhat distant from each other and inserted opposite to the hind margin of the preoperculum; the tail tapers almost to a point. The 
lateral line is a continuous tract not covered by scales, running parallel to and close to the dorsal profile and disappearing in the posterior third of the tail; it is separated from the dorsal fin by about six series of scales.

The color was probably pink, with black vertical fins; cavity of the mouth and gills black.

Length, $14 \frac{1}{2}$ inches.

Locality, Challenger Station 235, at a depth of 565 fathoms. Japan. (Günther.)

Not seen by us.

(quinquarius, in fives.)

\section{SUMMARY.}

Family I. Congrogadide.

1. Hierichthys Jordan and Fowler.

1. encryptes Jordan and Fowler; Miyakoshima.

Family II. ZoArCide.

2. Zoarces Cuvier.

2. elongatus Kner; Iwani, Hakodate, Sagalin, Tishima.

\section{Lycenchelys Gill.}

3. pæcilimon Jordan and Fowler; Matsushima Bay.

4. Bothrocara Bean.

4. zesta Jordan and Fowler; Sagami Bay.

Family III. Carapide.

5. Carapus Rafinesque (Fierasfer Cuvier).

5. kagoshimanus (Steindachner and Döderlein).

Family IV. Ophidide.

6. Otophidium Gill.

6. asiro Jordan and Fowler; Misaki.

Family V. Brotulide.

7. Brotula Cuvier.

7. multibarbata Schlegel; Formosa.

8. Myxocephalus Steindachner and Döderlein.

8. japonicus Steindachner and Döderlein.

9. Sirembo Bleeker.

9. imberbis (Schlegel); Tokyo, Misaki, Wakanoura, Nagasaki.

10. Bassogigas Gill.

10. grandis Günther. 
11. Watasea Jordan and Snyder.

11. sivicola Jordan and Snyder; Misaki, Yokohama.

12. Hoplobrotula Gill.

12. armata (Schlegel); Nanaura.

13. Porogadus Goode and Bean.

13. güntheri Jordan and Fowler; Sagami Bay.

14. Pteroidonus Günther.

14. quinquarius Günther. 


\section{$2 \mathrm{BHL}$ Biodiversity Heritage Library}

Jordan, David Starr and Fowler, Henry W. 1902. "A review of the ophidioid fishes of Japan." Proceedings of the United States National Museum 25(1303), 743-766. https://doi.org/10.5479/si.00963801.25-1303.743.

View This Item Online: https://www.biodiversitylibrary.org/item/32399

DOI: https://doi.org/10.5479/si.00963801.25-1303.743

Permalink: https://www.biodiversitylibrary.org/partpdf/9173

\section{Holding Institution}

Smithsonian Libraries

\section{Sponsored by}

Smithsonian

\section{Copyright \& Reuse}

Copyright Status: NOT_IN_COPYRIGHT

This document was created from content at the Biodiversity Heritage Library, the world's largest open access digital library for biodiversity literature and archives. Visit BHL at https://www.biodiversitylibrary.org. 